\title{
Tissue-specific regulation of IRS-1 in unilaterally nephrectomized rats
}

A.D. Sasse, E. Chen, C.R.O. Carvalho, J.A.R. Gontijo, S.L. Brenelli and M.J.A. Saad
Departamento de Clínica Médica, Faculdade de Ciências Médicas, Universidade Estadual de Campinas, Campinas, SP, Brasil

\section{Correspondence}

M.J.A. Saad

Departamento de Clínica Médica

Faculdade de Ciências Médicas

Universidade Estadual de Campinas

13083-970 Campinas, SP

Brasil

Fax: 55 (019) 239-3114

Research supported by FAPESP

and CNPq.

Received April 10, 1997

Accepted July 29, 1997

\section{Abstract}

Insulin stimulates the tyrosine kinase activity of its receptor, resulting in the phosphorylation of its cytosolic substrate, insulin receptor substrate 1 (IRS-1). IRS-1 is also a substrate for different peptides and growth factors, and a transgenic mouse "knockout" for this protein does not have normal growth. However, the role of IRS-1 in kidney hypertrophy and/or hyperplasia was not investigated. In the present study we investigated IRS-1 protein and tyrosine phosphorylation levels in the remnant kidney after unilateral nephrectomy (UNX) in 6week-old male Wistar rats. After insulin stimulation the levels of insulin receptor and IRS-1 tyrosine phosphorylation were reduced to $79 \pm 5 \%(\mathrm{P}<0.005)$ and $58 \pm 6 \%(\mathrm{P}<0.0001)$, respectively, of the control (C) levels, in the remnant kidney. It is possible that a circulating factor and/or a local (paracrine) factor playing a role in kidney growth can influence the early steps of insulin action in parallel. To investigate the hypothesis of a circulating factor, we studied the early steps of insulin action in liver and muscle of unilateral nephrectomized rats. There was no change in pp 185 tyrosine phosphorylation levels in liver (C $100 \pm 12 \%$ vs UNX $89 \pm 9 \%$, NS) and muscle (C 100 $\pm 22 \%$ vs UNX $91 \pm 17 \%$, NS), and also there was no change in IRS1 phosphorylation levels in both tissues. These data demonstrate that after unilateral nephrectomy there is a decrease in insulin-induced insulin receptor and IRS-1 tyrosine phosphorylation levels in kidney but not in liver and muscle. It will be of interest to investigate which factors, probably paracrine ones, regulate these early steps of insulin action in the contralateral kidney of unilaterally nephrectomized rats.

One of the earliest cellular responses to stimulation by insulin is the activation of insulin receptor kinase and tyrosine phosphorylation of insulin receptor $\beta$ subunit and pp185, a cytoplasmic phosphoprotein found in most cells and tissues (1). A component of the pp185 band was purified and cloned from several sources $(2,3)$. The cloned pro-
Key words - Insulin receptor

- Insulin receptor substrate

- Unilateral nephrectomy

- Insulin action 
including IGF-1 and GH, and a transgenic mouse "knockout" for this protein does not have normal growth. IGF-1 and its receptor have been involved in kidney compensatory hypertrophy after unilateral nephrectomy (UNX) or diabetes. However, the role of IRS-1 in kidney hypertrophy and/or hyperplasia was not investigated. The first aim of this study was to investigate IRS-1 protein and tyrosine phosphorylation levels in the remnant kidney after UNX.

Male Wistar rats (6 weeks old) underwent unilateral left nephrectomy (the kidneys were trimmed of fat and capsule and the adrenal glands were left intact), as described previously (6), or sham operation, where a flank incision was made and the left kidney was manipulated, but not removed. The animals recovered and received food and water ad libitum. After seven days, the rats were anesthetized with sodium amobarbital (15 $\mathrm{mg} / \mathrm{kg}$ body weight, intraperitoneally) and used in experiments 10-15 min later, as soon as anesthesia was confirmed by the loss of pedal and corneal reflexes. The abdominal cavity was opened, the vena cava exposed and $0.5 \mathrm{ml}$ of normal saline $(0.9 \% \mathrm{NaCl})$ containing or not $10 \mu \mathrm{M}$ insulin was injected. After 30 or $90 \mathrm{~s}$, fragments of liver and muscle, respectively, were removed, minced coarsely and immediately homogenized in approximately 6 volumes of solubilization buffer A using a Polytron PTA 20S generator (Brinkmann Instruments, model PT 10/35) operated at maximum speed for $30 \mathrm{~s}$ in a water bath maintained at $100^{\circ} \mathrm{C}$ as previously described (7-9). To investigate IRS-1 phosphorylation in kidney, saline with or without insulin was infused into the vena cava and the remnant kidney was extracted $90 \mathrm{~s}$ later in the same way as described for liver and muscle. Solubilization buffer A contained 1\% SDS, 50 mM HEPES, pH 7.4, $100 \mathrm{mM}$ sodium pyrophosphate, $100 \mathrm{mM}$ sodium fluoride, $10 \mathrm{mM}$ EDTA, and $10 \mathrm{mM}$ sodium vanadate. The homogenates were then boiled for $10 \mathrm{~min}$ and cooled in an ice bath for $40 \mathrm{~min}$. In some experiments, kidney, liver and muscle were excised and homogenized with a Polytron apparatus in 6 volumes of homogenization buffer $B$ cooled in an ice bath. The composition of buffer B was the same as buffer A except that $1 \%$ Triton X-100 replaced 1\% SDS and $2 \mathrm{mM}$ PMSF and $0.1 \mathrm{mg} / \mathrm{ml}$ aprotinin were added. Both extracts were centrifuged at $100,000 \mathrm{~g}$ $(55,000 \mathrm{rpm})$ at $4^{\circ} \mathrm{C}$ in a Beckman $70.1 \mathrm{Ti}$ rotor for $30 \mathrm{~min}$ to remove insoluble material, and the resulting supernatant was used for the experiments. The kidney, liver and muscle homogenized in buffer B were used for immunoprecipitation with anti-IRS-1 antibody and Protein A-Sepharose 6 MB.

The samples were treated with Laemmli sample buffer (10) containing $100 \mathrm{mM}$ DTT and heated in a boiling water bath for $4 \mathrm{~min}$. For total extracts, similar size samples (150 $\mu \mathrm{g}$ of protein) were submitted do SDS/PAGE (6.5\% Tris/acrylamide) in a Bio-Rad miniature slab gel apparatus (11). Electrotransfer of proteins from the gel to nitrocellulose was performed for $2 \mathrm{~h}$ at $100 \mathrm{~V}$ (constant) in the Bio-Rad miniature transfer apparatus (Miniprotean), as described by Towbin et al. (12) but with $0.02 \%$ SDS added to the transfer buffer to enhance the elution of high molecular mass protein. Nonspecific protein binding to the nitrocellulose was reduced by preincubating the filter overnight at $4^{\circ} \mathrm{C}$ in blocking buffer (3\% BSA, $10 \mathrm{mM}$ Tris, $150 \mathrm{mM}$ $\mathrm{NaCl}$, and $0.02 \%$ Tween 20 ). The prestained molecular mass standards used were myosin $(205 \mathrm{kDa}), \beta$-galactosidase $(116 \mathrm{kDa}), \mathrm{BSA}$ $(80 \mathrm{kDa})$ and ovalbumin $(49.5 \mathrm{kDa})$. The nitrocellulose blot was incubated with antiphosphotyrosine antibody $(1 \mu \mathrm{g} / \mathrm{ml})$ for $4 \mathrm{~h}$ at $22^{\circ} \mathrm{C}$. The blots were subsequently incubated with $2 \mu \mathrm{Ci}$ of ${ }^{125}$ I-Protein A $(30 \mu \mathrm{Ci} /$ $\mu \mathrm{g})$ in $10 \mathrm{ml}$ of blocking buffer for $1 \mathrm{~h}$ at $22^{\circ} \mathrm{C}$ and washed for $2 \mathrm{~h}$. ${ }^{125}$ I-Protein A bound to the antibodies was detected by autoradiography using preflashed Kodak 
XAR film with Cronex Lightning Plus intensifying screens at $-70^{\circ} \mathrm{C}$ for $12-48 \mathrm{~h}$. Band intensities were quantified by densitometry (Molecular Dynamics) of the developed autoradiogram.

In the present study we evaluated the effect of UNX on insulin receptor and IRS-1 phosphorylation in the remnant kidney. There was no change in insulin receptor protein levels as determined by immunoblotting with an antibody to the $\mathrm{C}$-terminus of the insulin receptor (data not shown). Following insulin infusion into the vena cava, a phosphotyrosine band of $95 \mathrm{kDa}$, previously identified as the insulin receptor $\beta$ subunit $(1,13,14)$, appeared and became prominently phosphorylated. The level of phosphorylation of this band was reduced to $79 \pm 5 \%(\mathrm{P}<0.005)$ in the remnant kidney. In addition to the 95$\mathrm{kDa}$ band seen after insulin injection, a broad band migrating between 165 and $185 \mathrm{kDa}$ was also detectable (Figure 1A). This band is known as pp185 and IRS-1 is one component of this band (15). The phosphorylation of pp 185 was reduced to $58 \pm 6 \%(\mathrm{P}<0.0001)$ in the remnant kidney. In order to characterize IRS-1 phosphorylation after insulin stimulation, we immunoprecipitated kidney extracts with anti-IRS-1 antibody and immunoblotted these with anti-IRS-1 and antiphosphotyrosine antibody (Figure 1B). There was no change in IRS-1 protein levels in the remnant kidney. However, after insulin stimulation IRS-1 tyrosine phosphorylation was reduced to $41 \pm 5 \%(\mathrm{P}<0.0001)$ in the kidney of UNX rats compared to the kidney of control rats. The mechanism(s) responsible for the reduction in insulin receptor and IRS1 tyrosine phosphorylation in the remnant kidney after 7 days of UNX have not been elucidated. The regulation of insulin receptor and IRS-1 is under the control of different situations such as fasting, obesity, hormones and diabetes. We have previously demonstrated that in other tissues the excess of cortisol (16), glucagon (7), epinephrine
(9), and GH (17) and also hyperinsulinemia (13) can modulate the early steps of insulin action by inducing a reduction in insulin receptor and IRS-1 phosphorylation. However, none of these hormones is in excess in our animal model of kidney growth. It is possible that a circulating factor and/or a local (paracrine) factor that plays a role in kidney growth can influence the early steps of insulin action in parallel. If there is a

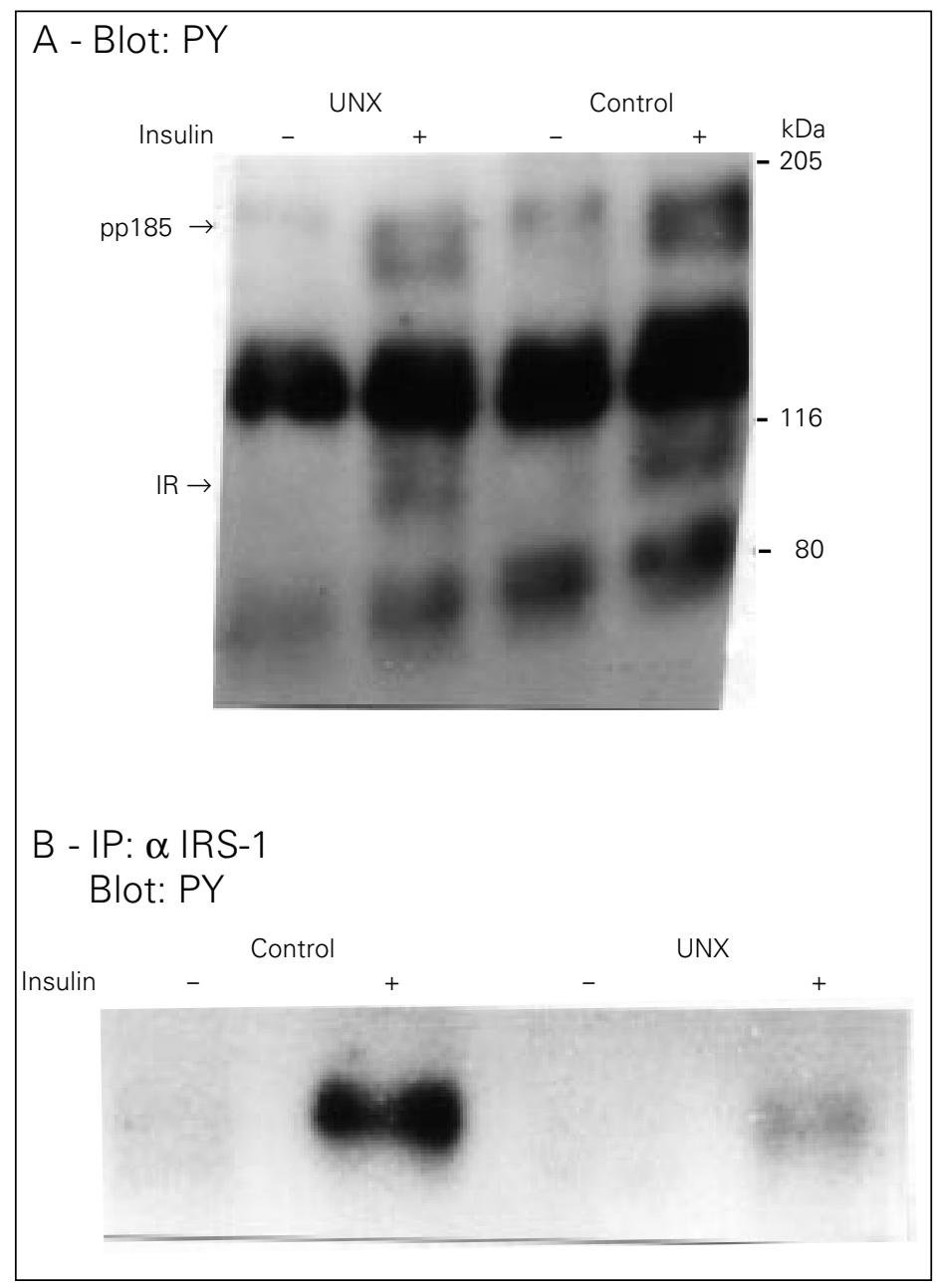

Figure 1 - $A$, Insulin receptor (IR) and pp185 tyrosine phosphorylation in remnant kidney tissue after saline (-) or saline plus $10 \mu \mathrm{M}$ insulin (+) in unilaterally nephrectomized (UNX) rats, compared with controls. The tissue was extracted as described in Methods and immunoblotting (Blot) of total tissue extracts was performed with anti-phosphotyrosine antibody (PY) and ${ }^{125}$-Protein A. B, Effect of unilateral nephrectomy on insulin receptor substrate 1 (IRS-1) in the rat remnant kidney. Kidney extracts from controls and unilaterally nephrectomized rats were immunoprecipitated (IP) with anti-IRS-1 antibody ( $\alpha$ IRS-1) and then immunoblotted with anti-phosphotyrosine antibody. 
Figure 2 - Effect of unilateral nephrectomy (UNX) on insulin receptor substrate 1 (IRS-1) in the rat liver and muscle. The liver extracts from controls and unilaterally nephrectomized rats were immunoprecipitated (IP) with anti-IRS-1 antibody $(\alpha$ IRS- 1 ) and then immunoblotted (Blot) with antiphosphotyrosine antibody (PY) (A). The same procedure was applied to muscle (B).

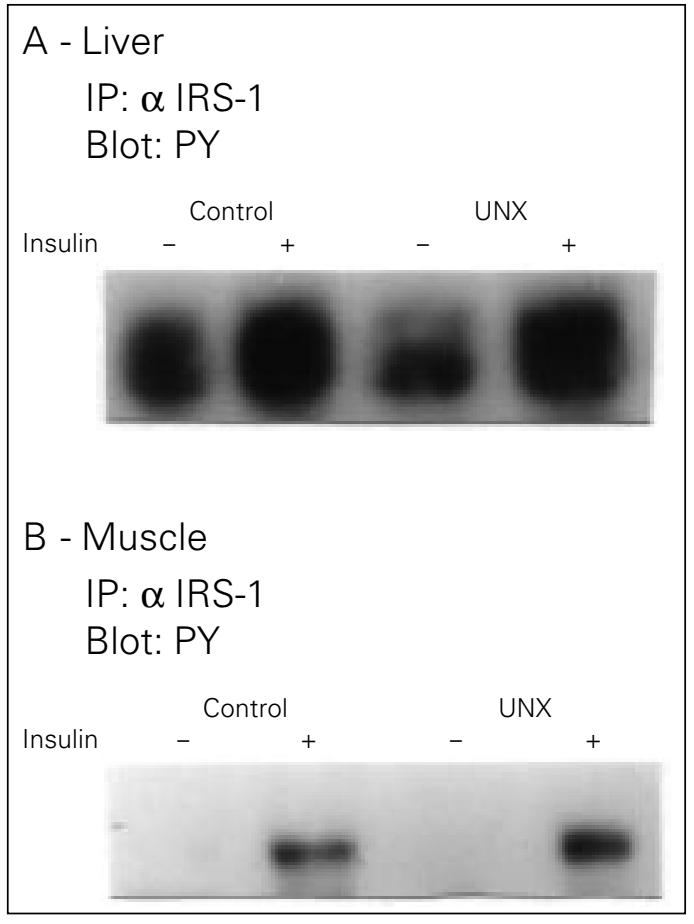

circulating factor that can regulate the early steps of insulin action in kidney, it may also modulate insulin receptor and IRS-1 in other tissues such as liver and muscle. To investigate this possibility we studied the early steps in insulin action in liver and muscle of unilateral nephrectomized rats. The experiments were performed as described above, except that we infused insulin into the portal vein, and extracted liver and muscle as described above. The results of total tissue extracts showed that in liver there was no change in pp185 phosphorylation levels (C $100 \pm 12 \%$ vs UNX $89 \pm 9 \%$, NS). In accordance, after immunoprecipitation with antiIRS-1 antibody and blotting with anti-phosphotyrosine antibody there was also no change in IRS-1 tyrosine phosphorylation in the liver of UNX rats (Figure 2A). In muscle the results were very similar with no change in insulin-induced pp185 phosphorylation (C $100 \pm 22 \%$ vs UNX $91 \pm 17 \%$, NS) and also in IRS-1 tyrosine phosphorylation (Figure $2 \mathrm{~B}$ ) in UNX rats.

In summary, the data demonstrated that after UNX there was a decrease in insulininduced insulin receptor and IRS-1 tyrosine phosphorylation levels in the remnant kidney but not in liver and muscle. It will be of interest to determine which factors, probably paracrine ones, regulate these early steps of insulin action in the contralateral kidney of UNX rats.

\section{References}

1. White MF \& Kahn CR (1994). The insulin signalling system. Journal of Biological Chemistry, 269: 1-5.

2. Sun $X J$, Rothenberg $P L$, Kahn $C R$, Baker $J M$, Araki E, Wilden $P$, Cahill DA, Goldstein BJ \& White MF (1991). Structure of the insulin receptor substrate-1 (IRS-1) defines a unique signal transduction protein. Nature, 352: 73-77.

3. Araki $E$, Sun $X J$, Haag III BL, Chuang LM, Zhang $Y$, Yang-Feng TL, White MF \& Kahn CR (1993). Human skeletal muscle insulin receptor substrate-1: characterization of the cDNA, gene and chromosomal localization. Diabetes, 42: 1041-1054.

4. Saad MJA, Velloso LA \& Carvalho CRO (1995). Angiotensin II induces tyrosine phosphorylation of insulin receptor substrate 1 and its association with phosphatidylinositol 3-kinase in rat heart. Biochemical Journal, 310: 741-744.
5. Argetsinger LS, Hsu GW, Myers MG, Billestrup N, White MF \& Carter-Su C (1995). Growth hormone, interferon- $\gamma$ and leukemia inhibitory factor promoted tyrosyl phosphorylation of insulin receptor substrate-1. Journal of Biological Chemistry, 270: 14685-14692.

6. Flyvbjerg A, Ussing OT, Naera R, Ingerslev J \& Orskov H (1988). Kidney tissue somatomedin $\mathrm{C}$ and initial renal growth in diabetic and uninephrectomised rats. Diabetologia, 31: 310-314.

7. Saad MJA, Hartmann LGC, Carvalho DS, Galoro CAO, Brenelli SL \& Carvalho CRO (1995). Effect of glucagon on insulin substrate-1 (IRS-1) phosphorylation and association with phosphatidylinositol-3 kinase (PI-3 kinase). FEBS Letters, 370: 131-134.
8. Carvalho CRO, Brenelli SL, Silva AC, Nunes ALB, Velloso LA \& Saad MJA (1996). Effect of aging on insulin receptor, insulin receptor substrate-1, and phosphatidylinositol-3 kinase in liver and muscle of rats. Endocrinology, 137: 151-159.

9. Saad MJA, Hartmann DSC, Galoro CAO, Brenelli SL \& Carvalho CRO (1995). Modulation of the early steps in insulin action in liver and muscle of epinephrine treated rats. Endocrine, 3: 755-759.

10. Laemmli UK (1970). Cleavage of structural proteins during the assembly of the head of bacteriophage T4. Nature, 227: 680-685.

11. Bradford MM (1976). A rapid and sensitive method for quantitation of microgram quantities utilizing the principle of protein dye binding. Analytical Biochemistry, 227: 248-254. 
12. Towbin H, Staehlin J \& Gordon J (1979). Electrophoretic transfer of proteins from polyacrylamide gels to nitrocellulose sheets. Procedure and some applications. Proceedings of the National Academy of Sciences, USA, 76: 4350-4354.

13. Saad MJA, Araki E, Miralpeix M, Rothenberg $\mathrm{PL}$, White MF \& Kahn CR (1992). Regulations of insulin receptor substrate-1 in liver and muscle of animal models of insulin resistance. Journal of Clinical Investigation, 90: 1839-1849.
14. Kasuga M, Karlson FA \& Kahn CR (1982) Insulin stimulates the phosphorylation of the 95,000 dalton subunit of its own receptor. Science, 215: 185-187.

15. Sun XJ, Wang LM, Zhang $Y$, Yenush LP, Myers MG, Glasheen EM, Lane WS, Pierce JH \& White MF (1995). Role of IRS-2 in insulin and cytokine signalling. Nature, 377: 173-177.
16. Saad MJA, Folli F, Kahn JA \& Kahn CR (1993). Modulation of insulin receptor substrate-1 (IRS-1) and phosphatidylinositol 3-kinase in liver and muscle of dexamethasone treated rats. Journal of Clinical Investigation, 92: 2065-2072.

17. Thirone ACP, Carvalho CRO, Brenelli SL, Velloso LA \& Saad MJA (1997). Effect of chronic $\mathrm{GH}$ treatment on insulin signal transduction in rat tissues. Molecular and Cellular Endocrinology, 130: 33-42. 